The Egyptian Journal of Biochemistry \& Molecular Biology VOL 34 (N.1\&2) 23-38 December. 2016

\title{
POSSIBLE INVOLVEMENT OF BRAIN-DERIVED NEUROTROPHIC FACTOR IN MALE INFERTILITY
}

\author{
Adel A. Zalata, Amany Atwa, Naglaa Mokhtar, Mohamed khaled \\ MEDICAL BIOCHEMISTRY DEPARTMENT, FACULTY OF \\ MEDICINE, MANSOURA UNIVERSITY EL-GOUMHORIA ST., \\ MANSOURA, EGYPT
}

Received 15/2/2016 - Accepted 21/3/2016

\begin{abstract}
Brain-derived neurotrophic factor (BDNF) plays a role in the development of various non-neuronal tissues, as the reproductive system. BDNF transcript and protein has been detected in testis and sperms. The present work aimed to assess the possible involvement of BDNF mRNA expression in sperm functions, hormonal profile and oxidative stress in male infertility. Semen samples from 106 individuals attended the Andrology Outpatient Clinic, Mansoura University Hospital were included in the present study. They were grouped into normozoospermia $(n=31)$, asthenozoospermia $(n=24)$, astheno-teratozoospermia $(n=25)$ and Oligo-astheno-teratozoospermia $(n=26)$. Reverse transcription-PCR (RT-PCR) for brain-derived neurotrophic factor (BDNF) mRNA expression was done for semen samples. The present study demonstrated that BDNF mRNA expression was significantly decreased in the infertile samples compared with the normozoospermic group. BDNF mRNA expression was significantly positively correlated to testosterone levels $(\mathrm{r}=0.337, \mathrm{p}=0.0004)$ while, negatively correlated to folliclestimulating hormone $(\mathrm{FSH})(\mathrm{r}=-0.5, \mathrm{p}<0.0001)$ and malondialdehyde (MDA) /sperm levels $(\mathrm{r}=-0.735, \mathrm{p}<0.0001)$. Also, the study showed significant positive correlation $(\mathrm{p}<0.0001)$ between BDNF mRNA expression and sperm motility, velocity, linear velocity and linearity index. Stepwise multiple regression analysis showed that sperm morphology and alpha glucosidase may be possible determinants that influence changes of BDNF expression. BDNF mRNA may directly affect sperm functions and may be implicated in the pathophysiology

* Correspondence Author (e mail: adel_zalata@yahoo.com)


of infertility. Furthermore, BDNF may have protection against oxidative stress.

Keywords: Brain-Derived Neurotropic Factor (BDNF) mRNA expression, Infertility, Sperm function, Oxidative stress.

\section{INTRODUCTION}

Neurotrophins and their receptors have been shown to be expressed during testicular development in the germ cells and also in somatic cells; Sertoli and Leydig cells in fetal and adult testicles, in both rodents and humans (Müller et al. 2006 and Perrard et al. 2007) suggesting that neurotrophins play critical roles in testicular development and spermatogenesis (Seifer et al., 2002 and Zheng et al., 2011). Both the mRNAs encoding BDNF and neurotrophic tyrosine kinase receptor, type 2 (Ntrk2) and the corresponding proteins have been detected in ejaculated bull sperm. The BDNF protein was found in the head, neck, and tail of the sperm cells, whereas Ntrk2 was strongly localized in the acrosome (Li et al., 2012, Wang et al., 2013). Furthermore, BDNF/ Ntrk2 signaling affected sperm viability, mitochondrial activity, and apoptosis (Li et al., 2012).

Spermatozoa are particularly susceptible to oxidative injury due to the abundance of plasma membrane polyunsaturated fatty acids. Seminal reactive oxygen species (ROS) is believed to be one of the main factors in the pathogenesis of sperm dysfunction and sperm DNA damage in male infertility (Zalata et al., 1998 and Zini et al., 2009).

The aim of the present work is to assess the role of BDNF mRNA in sperm functions, and the relation between sperm BDNF mRNA expression and the hormonal profile and oxidative stress in male infertility.

\section{MATERIALS AND METHODS}

A total of 106 men were included in the current study. Blood and semen samples were obtained from men attending the Andrology Outpatient Clinic, Mansoura University Hospital. Informed consent was obtained from all participants. They were grouped into control (normozoospermia, N) $(n=31)$, asthenozoospermia $(A)(n=24)$, astheno-teratozoospermia (AT) $(n=25)$, and oligo-astheno-teratozoospermia (OAT) $(n=26)$ 
according to the recommendation of WHO (2010). Sil-select gradient (Fertipro, Belguim) has been performed on the pellet of spermatoztoa to select spermatozoa only and avoid contamination with pus cells. Sperm parameters are detected by Computer assisted semen analysis (Autosperm Fertipro, Belguim) (Hinting et al., 1988). Acrosine activity of spermatozoa by gelatinolysis test was performed. Th halo formation rate, the percentageof halo formation and the acrosin activity index were determined by evaluating 100 spermatozoa (Henkel et al., 1995). Both Seminal Malondialdehyde (MDA) (Draper et al., 1993) and alphaglucosidase (Guerin et al., 1986) were analyzed by colorimetric methods. The results of MDA were calculated as MDA per nmoles $10^{8}$ spermatozoa (Zalata et al., 2004). FSH, Estradiol, LH, testosterone \& Prolactin were measured by ELISA. All procedures were performed according to the manufacturer's instructions. Sperm morphology was evaluated by phase contrast microscope and Sperm Mac stain (Fertipro, Belguim). The study was approved by the Ethical Committee of Medical Faculty in Mansoura University.

Reverse transcription-PCR for brain-derived neurotrophic factor (BDNF) mRNA expression: Semen samples were collected, and total RNA was extracted using RNeasy mini kit (Qiagen, cat no. 74104) as described in the manufacturer's instructions. The purity of RNA was checked at $260 \mathrm{~nm}$ using the Nanodrop spectrophotometer, NanoPhotometer® P-Class (Implen, Germany). The absence of RNA degradation was confirmed by electrophoresis on a $1.5 \%$ agarose gel electrophoresis containing ethidium bromide. First-strand cDNA was generated by using Maxima First Strand cDNA Synthesis Kit (Thermo Scientific, U.S.A). Brain-derived neurotrophic factor and B-actin were amplified using a PTC-200 thermal cycler (MJ Research, Essex, UK). Primers were prepared in accordance with a previous study (Kerschensteiner et al, 1999). Primer sequences were as follows: 


\begin{tabular}{|c|c|c|c|}
\hline Primer & Sequence & $\begin{array}{c}\text { Product } \\
\text { length } \\
\text { (bp) }\end{array}$ & References \\
\hline $\begin{array}{l}\text { Brain } \\
\text { Derived } \\
\text { Neurotrophic } \\
\text { Factor } \\
\text { (BDNF) }\end{array}$ & $\begin{array}{l}\text { F: 5'- AGC GTG AAT GGG CCC } \\
\text { AAG GCA -3' } \\
\text { R: } 5^{\prime} \text { - TGT GAC CGT CCC GCC } \\
\text { CGA CA-3' }\end{array}$ & 363 & $\begin{array}{l}\text { (Kerschensteiner } \\
\text { et al., 1999) }\end{array}$ \\
\hline B-actin & $\begin{array}{l}\text { F: } 5^{\prime}-\text { GAC CTG ACT GAC TAC } \\
\text { CTC ATG A-3' } \\
\text { R: } 5^{\prime} \text { - TGA TCT CCT TCT GCA } \\
\text { TCC TGT C }-3^{\prime}\end{array}$ & 403 & (Ma et al., 2002) \\
\hline
\end{tabular}

The cycle profile was as follows: initial denaturation at $94^{\circ} \mathrm{C}$ for 5 minutes, followed by 40 cycles of denaturation at $94^{\circ} \mathrm{C}$ for 30 seconds, annealing at $60^{\circ} \mathrm{C}$ for 1 minute and elongation at $72^{\circ} \mathrm{C}$ for 1 minute, and a final incubation at $72^{\circ} \mathrm{C}$ for 10 minutes.

\section{Detection of the amplified RT-PCR products:}

The PCR products were electrophoresed on 2\% agarose gel stained with ethidium bromide and DNA was visualized via light UV Transilluminator (Model TUV-20, OWI. Scientific, Inc. 800 2425560) and photographed under fixed conditions (the distance, the light and the zoom). The results were analyzed with scion image ${ }^{\circledR}$ release Alpha 4.0.3.2. software for windows ${ }^{\circledR}$ which performs bands detection and conversion to peaks. Area under each peak was calculated in square pixels and used for quantification. Brain-derived neurotrophic factor (BDNF) mRNA expression level was determined by calculating the ratio between the square pixel values of the target bands in relation to the control bands B-actin, housekeeping gene for Rt-PCR ( Figure1).

Statistical analysis was done by using MedCalc ${ }^{\circledR}$ program version 10.0.1 (Schoonjans et al., 1995).

\section{RESULTS}

Table (1) showed semen parameters in all studied groups expressed as median and range. Sperm function tests including acrosine activity index, halo diameter, halo percent, and alpha-glucosidase activity showed statistical significant difference between fertile and all infertile groups as shown in (table 2). The hormonal profile showed significant increase in FSH levels in AT and OAT groups compared 
with $\mathrm{N}$ control group. However, there was significant decrease of testosterone in OAT compared with $\mathrm{N}$ group (table 3). The current work showed that BDNF mRNA expression levels were positively correlated to testosterone levels $(\mathrm{r}=0.337, \mathrm{p}=0.0004)$ while, negatively correlated to FSH $(\mathrm{r}=-0.5, \mathrm{p}=<0.0001)$ and MDA $/ 10^{8} \mathrm{x}$ sperm levels $(\mathrm{r}=-0.735, \mathrm{p}=<0.0001)$.

Table (1): Semen parameters of all studied groups (median and range)

\begin{tabular}{|c|c|c|c|c|}
\hline Semen parameters & $\begin{array}{l}\operatorname{group}(\mathbf{N}) \\
\mathbf{n}=\mathbf{3 1}\end{array}$ & $\begin{array}{c}\text { group } \\
\text { (A) } \\
\mathbf{n}=24\end{array}$ & $\begin{array}{c}\text { group } \\
\text { (AT) } \\
\mathbf{n}=\mathbf{2 5}\end{array}$ & $\begin{array}{c}\text { group } \\
\text { (OAT) } \\
\mathbf{n}=\mathbf{2 6}\end{array}$ \\
\hline Volume (ml) & $\begin{array}{l}3.5 \\
2-7\end{array}$ & $\begin{array}{c}3.5 \\
1-7.5\end{array}$ & $\begin{array}{c}3.5 \\
1.5-8.2\end{array}$ & $\begin{array}{c}3.5 \\
1-9.2\end{array}$ \\
\hline $\begin{array}{c}\text { Concentration (million / } \\
\mathrm{ml})\end{array}$ & $\begin{array}{c}75.73 \\
44.8-96.0\end{array}$ & $\begin{array}{c}53.06 \\
24.96- \\
67.2\end{array}$ & $\begin{array}{l}29.87 \\
29.8- \\
53.33\end{array}$ & $\begin{array}{c}9.07 \\
3.1- \\
18.84\end{array}$ \\
\hline Grade A motility (\%) & $\begin{array}{c}53 \\
36-60\end{array}$ & $\begin{array}{c}33 \\
14-42\end{array}$ & $\begin{array}{c}14 \\
0-28\end{array}$ & $\begin{array}{c}4 \\
0-24\end{array}$ \\
\hline Grade A+B motility (\%) & $\begin{array}{c}61 \\
51-67 \\
\end{array}$ & $\begin{array}{c}38 \\
31-45\end{array}$ & $\begin{array}{c}28 \\
2-42\end{array}$ & $\begin{array}{l}17.5 \\
4-39 \\
\end{array}$ \\
\hline Velocity $(\mu \mathrm{m} / \mathrm{sec})$ & $\begin{array}{c}70 \\
63.4-86.6\end{array}$ & $\begin{array}{c}50.6 \\
31.8- \\
85.3\end{array}$ & $\begin{array}{c}37.6 \\
17.6- \\
69.9\end{array}$ & $\begin{array}{l}27.05 \\
8.8-37.2\end{array}$ \\
\hline Linear velocity $(\mu \mathrm{m} / \mathrm{sec})$ & $\begin{array}{c}60.1 \\
42.9-70.7\end{array}$ & $\begin{array}{l}27.25 \\
18.1- \\
66.2\end{array}$ & $\begin{array}{l}19.4 \\
8.1- \\
31.4\end{array}$ & $\begin{array}{c}11.4 \\
1.3-20.8\end{array}$ \\
\hline Linearity index $(\mu \mathrm{m} / \mathrm{sec})$ & $\begin{array}{c}77.94 \\
67.67-86.32\end{array}$ & $\begin{array}{c}56.04 \\
37.18- \\
77.64\end{array}$ & $\begin{array}{c}59.54 \\
31.44- \\
54.26\end{array}$ & $\begin{array}{c}42.35 \\
14.77- \\
55.91\end{array}$ \\
\hline $\begin{array}{c}\text { Normal morphology } \\
(\%)\end{array}$ & $\begin{array}{c}54 \\
42-64\end{array}$ & $\begin{array}{c}43.5 \\
30-64\end{array}$ & $\begin{array}{c}12 \\
2-22\end{array}$ & $\begin{array}{c}3 \\
0-18\end{array}$ \\
\hline WBCs ( million / ml) & $\begin{array}{c}0.6 \\
0.4-0.9\end{array}$ & $\begin{array}{c}0.6 \\
0.4-3.6\end{array}$ & $\begin{array}{c}0.6 \\
0.6-4.4\end{array}$ & $\begin{array}{c}0.7 \\
0.4-4.8\end{array}$ \\
\hline Round cells & $\begin{array}{c}2.4 \\
0.3-3.4\end{array}$ & $\begin{array}{c}2.4 \\
1.6-4.4\end{array}$ & $\begin{array}{c}2.5 \\
1.4-5.6\end{array}$ & $\begin{array}{c}2.4 \\
0.4-6.4\end{array}$ \\
\hline
\end{tabular}


Table (2): Sperm functions of all studied groups (median and range)

\begin{tabular}{|c|c|c|c|c|}
\hline $\begin{array}{l}\text { Sperm } \\
\text { functions }\end{array}$ & $\begin{array}{l}(\mathrm{N}) \\
\mathrm{n}=\mathbf{3 1}\end{array}$ & $\begin{array}{l}\text { (A) } \\
n=24\end{array}$ & $\begin{array}{l}(\mathrm{AT}) \\
\mathrm{n}=\mathbf{2 5}\end{array}$ & $\begin{array}{l}\text { (OAT) } \\
n=26\end{array}$ \\
\hline Halo & $\begin{array}{l}17.4 \\
12.8-24.7\end{array}$ & $\begin{array}{l}15.2 * \\
11.1-18.4\end{array}$ & $\begin{array}{l}14.3^{*} \\
9.4-16.8\end{array}$ & $\begin{array}{l}10.4^{*} \\
9-14.6\end{array}$ \\
\hline Halo percent & $\begin{array}{l}75 \\
63-90\end{array}$ & $\begin{array}{l}62 * \\
44-80\end{array}$ & $\begin{array}{l}42 * \\
8-82\end{array}$ & $\begin{array}{l}12 * \\
6-66\end{array}$ \\
\hline Acrosine- index & $\begin{array}{l}12.72 \\
8.98-20.25\end{array}$ & $\begin{array}{l}\text { 10.01* } \\
5.5-13.98\end{array}$ & $\begin{array}{l}5.41 * \\
0.94-11.07\end{array}$ & $\begin{array}{l}1.22 * \\
0.55-9.57\end{array}$ \\
\hline$\alpha$-glucosidase & $\begin{array}{l}74.8 \\
45.4-90.7\end{array}$ & $\begin{array}{l}41.2 * \\
29.6-50.6\end{array}$ & $\begin{array}{l}34.1 * \\
22.9-46.5\end{array}$ & $\begin{array}{l}24.45^{*} \\
18.4-42.2\end{array}$ \\
\hline
\end{tabular}

* Significant at $\mathrm{p}<0.05$ comparison between the infertile groups and control group $(\mathrm{N})$.

Table (3): Blood Hormones of all studied groups (median - range)

\begin{tabular}{|c|c|c|c|c|}
\hline Blood hormone & $\begin{array}{l}\text { Group }(\mathbf{N}) \\
\mathrm{n}=31\end{array}$ & $\begin{array}{l}\text { Group (A) } \\
\mathbf{n}=24\end{array}$ & $\begin{array}{l}\text { Group } \\
(\mathrm{AT}) \\
\mathrm{n}=25\end{array}$ & $\begin{array}{l}\text { Group } \\
(\text { OAT) } \\
n=26\end{array}$ \\
\hline F.S.H (mIU/ml) & $\begin{array}{l}6.2 \\
3.9-9.6\end{array}$ & $\begin{array}{l}6.3 \\
4.5-9.8\end{array}$ & $\begin{array}{l}7.2 * \\
5.3-9.4\end{array}$ & $\begin{array}{l}9.8^{*} \\
6.4-22\end{array}$ \\
\hline LH (mIU/ml) & $\begin{array}{l}6.4 \\
4.5-9.3\end{array}$ & $\begin{array}{l}6.2 \\
4.2-7.5\end{array}$ & $\begin{array}{l}6.3 \\
3.4-9.7\end{array}$ & $\begin{array}{l}6.45 \\
3.1-12.4\end{array}$ \\
\hline Prolactin (ng/ml) & $\begin{array}{l}5.4 \\
3.5-8.6\end{array}$ & $\begin{array}{l}6.95 \\
2.5-11.4\end{array}$ & $\begin{array}{l}5.9 \\
2.3-12.4\end{array}$ & $\begin{array}{l}4.5 \\
2.4-10.8\end{array}$ \\
\hline Estradiol (pg/ml) & $\begin{array}{l}28 \\
24-45 \\
\end{array}$ & $\begin{array}{l}33 \\
20-55 \\
\end{array}$ & $\begin{array}{l}32 \\
22-88 \\
\end{array}$ & $\begin{array}{l}31 \\
20-123 \\
\end{array}$ \\
\hline $\begin{array}{l}\text { Testosterone } \\
(\mathrm{ng} / \mathrm{ml})\end{array}$ & $\begin{array}{l}789 \\
506-1106\end{array}$ & $\begin{array}{l}850 \\
543-1254\end{array}$ & $\begin{array}{l}754 \\
559-1077\end{array}$ & $\begin{array}{l}536.5^{*} \\
301-1200\end{array}$ \\
\hline
\end{tabular}

$\mathrm{n}=$ number of cases

* Significant at $\mathrm{p}<0.05$ comparison between the infertile groups and control group $(\mathrm{N})$.

28 
Analysis of variance revealed that sperm BDNF mRNA expression was significantly decreased from A, AT and OAT samples as compared with $\mathrm{N}$ control group $(\mathrm{p}<0.0001)$ (Figure 1, table 4). While, MDA $/ 10^{8}$ xsperm levels were significantly increased in infertile groups compared to fertile group (table 4).

Table (4): MDA nmole / $10^{8} \mathrm{x}$ sperm levels and BDNF mRNA expression levels in all studied groups (median and range)

\begin{tabular}{|c|c|c|c|c|}
\hline Variable & $\begin{array}{l}\text { Group }(N) \\
n=31\end{array}$ & $\begin{array}{l}\text { Group (A) } \\
\mathrm{n}=\mathbf{2 4}\end{array}$ & $\begin{array}{l}\text { Group }(\mathrm{AT}) \\
\mathrm{n}=\mathbf{2 5}\end{array}$ & $\begin{array}{l}\text { Group } \\
\text { (OAT) } \\
n=26\end{array}$ \\
\hline BDNF & $\begin{array}{l}2.29 \\
1.72-2.7\end{array}$ & $\begin{array}{l}1.74 * \\
1.37-2.18\end{array}$ & $\begin{array}{l}1.29 * \\
0.91-1.75\end{array}$ & $\begin{array}{l}0.74 * \\
0.42-1.2\end{array}$ \\
\hline $\begin{array}{l}\text { MDA nmole / } \\
10^{8} \text { x sperm }\end{array}$ & $\begin{array}{l}24.45 \\
12.22-76.79\end{array}$ & $\begin{array}{l}\text { 34.17* } \\
20.13-143.72\end{array}$ & $\begin{array}{l}58.32 * \\
21.75-166.45\end{array}$ & $\begin{array}{l}286.82 * \\
77.6- \\
1264.96\end{array}$ \\
\hline
\end{tabular}

$\mathrm{n}=$ number of cases

* Significant at $\mathrm{p}<0.05$ comparison between the infertile groups and control group $(\mathrm{N})$.

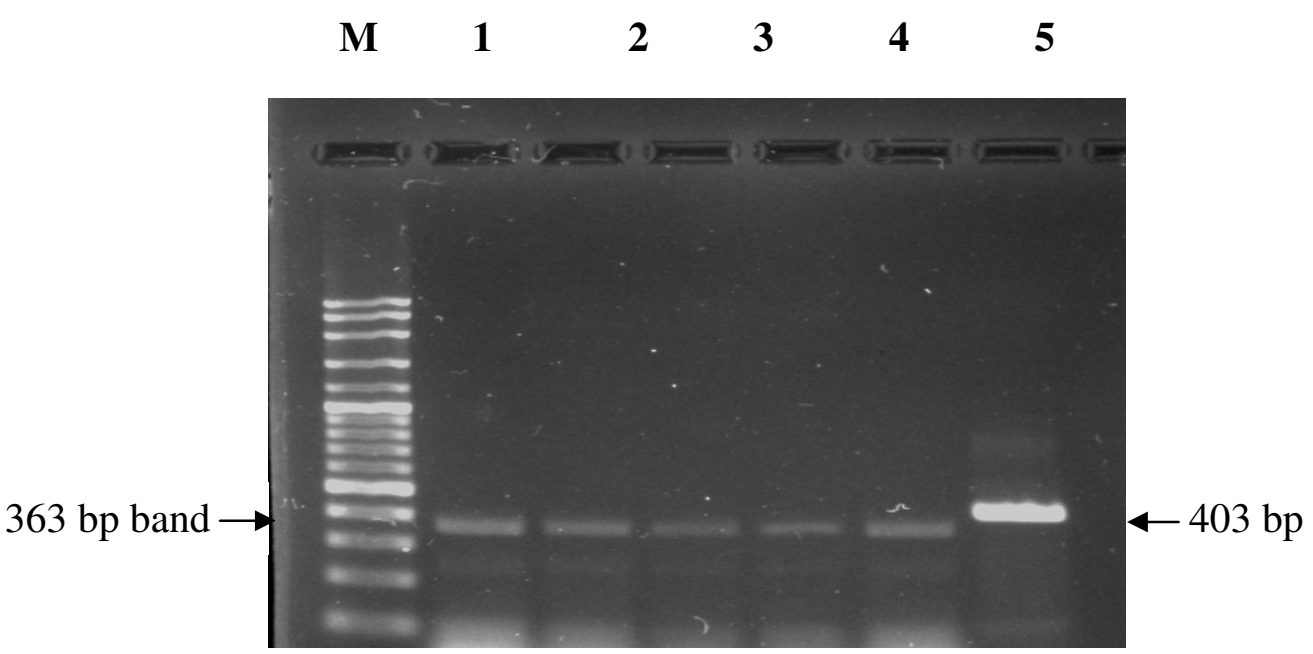

Figure 1 Expression analysis of BDNF mRNA from semen by RTPCR. Lanes 1\&5: normal fertile sample; lanes 2: Asthenozoospermia (A), lanes 3: Astheno-teratozoospermia (AT), lane 4: Oligo-astheno- 
teratozoospermia (OAT). M= 100 bp DNA ladder. The 363 bp bands represent amplification of BDNF; the $403 \mathrm{bp}$ band represents the internal control $\beta$ actin (lane 6).

However, BDNF mRNA expression was positively correlated to sperm motility, velocity, linear velocity, linearity index, and normal morphology and $\alpha$ - glucosidase activity using all samples as one group (table 5). Stepwise multiple regression analysis was done to detect factors which may influence changes of BDNF mRNA expression where sperm morphology (F-ratio 5.1, p<0.0001) and $\alpha$ glucosidase activity (F-ratio 2.4, $\mathrm{p}=0.02$ ) were found to be possible determinants.

Table (5): Correlation of BDNF mRNA expression and sperm characters of all studied groups $(n=106)$

\begin{tabular}{|l|c|}
\hline Variable & BDNF mRNA expression \\
\hline Grade A motility $(\%)$ & $\mathbf{r}=0.78^{*}$ \\
\hline Grade A+B motility $(\%)$ & $\mathbf{r}=0.8^{*}$ \\
\hline Velocity $(\mu \mathrm{m} / \mathrm{sec})$ & $\mathbf{r}=0.7^{*}$ \\
\hline Linear velocity $(\mu \mathrm{m} / \mathrm{sec})$ & $\mathbf{r}=\mathbf{0 . 7 6}^{*}$ \\
\hline Linearity index $(\mu \mathrm{m} / \mathrm{sec})$ & $\mathbf{r}=0.8^{*}$ \\
\hline Normal morphology $(\%)$ & $\mathbf{r}=\mathbf{- 0 . 2 7 ^ { * }}$ \\
\hline WBCs $($ million $/ \mathrm{ml})$ & $\mathbf{r}=0.75^{*}$ \\
\hline$\alpha$-glucosidase $(\mathrm{U} / \mathrm{L})$ & \\
\hline
\end{tabular}

$\mathbf{r}=$ Correlation Coefficient $*$ significant at $\mathbf{p}<0.05$ 


\section{DISCUSSION}

The neurotrophin family of proteins promotes the survival and differentiation of nerve cells and is thought to play an important role in development of reproductive tissues. Little is known about the influence of sex hormones on neurotrophin expression (Mirabella et al., 2006).

Results from this study confirmed the expression of BDNF mRNA from sperms that was in agreement with other studies (Aquila et al. 2005) where BDNF and the Ntrk2 were found to be expressed in ejaculated bovine sperm. In accordance with results from this study, a clinical study has shown that the levels of BDNF mRNA in the sperm and BDNF protein in the seminal plasma of a group of oligoasthenozoospermic men were lower than those from a fertile group, indicating that the decreases in the abundance of BDNF and its mRNA transcript may be involved in the pathogenesis of male infertility (Zheng et al. 2011).

Also, it is suggested that the BDNF/Ntrk2 system may promote the survival of testicular cells (Moon et al. 2005, Li et al. 2012, and Wang et al., 2013). The mechanism of action occurs by binding of BDNF to its receptor inducing Ntrk2 autophosphorylation that initiate several complex intracellular signal transduction cascades include Ras-mitogen-activated protein kinase (MAPK) pathway, the phosphatidylinositol 3-kinase (PI3K)-Akt pathway and the phospholipase $\mathrm{C}(\mathrm{PLC}) / \mathrm{Ca}^{2}+$ pathway. Activation of the phospholipase $\mathrm{C}$ (PLC)/ $/ \mathrm{Ca}^{2}+$ pathway leads to the release of calcium from the endoplasmic reticulum with activation of a calciumcalmodulin-dependent kinase II (Grande et al., 2010). Change in these signaling pathways due to low BDNF expression may mediate BDNF-promoted modifications of morphology. This subsequently may explain the results from this study where low BDNF expression may lead to abnormal morphology and hence abnormal functions causing infertility due to changes in the biological responses that are critical for cell survival and morphogenesis.

BDNF is an endothelial survival factor, deficiency of which results in reduced endothelial cell-cell contacts and apoptosis (Donovan et al., 2000). Animal models have demonstrated that apoptosis is the underlying mechanism of germ cell death during normal 
spermatogenesis (Sinha-Hikim et al., 1998). Thus, presence of higher rates of apoptosis could be another explanation for infertility in groups (A, AT \& OAT) where BDNF levels were low. This was in line with increased rate of apoptosis that has been observed in testicular biopsies from infertile men with varying degrees of testicular insufficiency (Jurisicova et al., 1999), and it was found that BDNF promoted apoptosis of bovine sperm occurs through Ntrk2 binding ( $\mathbf{L i}$ et al., 2012). This could be explained on the basis of that BDNF/Ntrk2 signaling pathway stimulates pro-survival signals (Douma et al., 2004) and modulates the cell death machinery directly by phosphorylating and thereby inhibiting the protein $\mathrm{BAD}$, a proapoptotic member of the Bcl-2 family (Bonni et al., 1999). A possible explanation of how low BDNF mRNA expression could relate to infertility is that BDNF has been identified as a key component of the hypothalamic pathway that controls energy homeostasis (Pedersen, 2011) not only in the brain, but also in peripheral tissues where it might contribute to the overall maintenance of energy balance (Ukropec et al., 2008). Expression of BDNF leads to phosphorylation of AMP-activated protein kinase (AMPK) and acetyl-coA carboxylase $\beta$ (ACC $\beta)$, as well as increases in mitochondrial fatty acid oxidation (Matthews et al., 2009). Blocking the BDNF/Ntrk2 signaling pathway affects sperm mitochondrial activity and viability (Li et al., 2012) leading to reduced sperm energy and function.

In the current study, the decreased testosterone levels in OAT may depress BDNF mRNA expression. The interaction between androgen and BDNF could be explained by the indirect effect of androgen via increasing the levels of the angiogenic factor vascular endothelial growth factor (VEGF), leading to an increase vascular network and endothelial cell synthesis of BDNF (Goldman and Chen, 2013). Also it is found that BDNF mRNA expression is decreased in skeletal muscles in aged rats due to decrease in the circulating androgens (Ming et al. 1999). This correlated decrease in testosterone and BDNF levels could outline the critical roles of both testosterone and BDNF in testicular development and spermatogenesis and formation of fully mature sperm. However, BDNF is expressed in the accessory glands of rat and it is found to be down-regulated by androgen hormones (Mirabella et al., 2006). The current study showed increased MDA level in seminal plasma of infertile groups associated with decreased 
BDNF mRNA expression; this was in agreement with the idea that BDNF has a protective effect against oxidative burden (Mattson et al., 1995). It was found that BDNF prevents the accumulation of peroxides and increases antioxidant enzymes in hippocampal neurons. Oxidative stress often leads to a loss of cell function, apoptosis, or necrosis. Elevated reactive oxygen species (ROS) production by spermatozoa has been associated with oligozoospermia (Aitken \& Buckingham, 1992 and Zalata et al., 1995) and was characterized by the presence of chromatin degradation in mature spermatozoa (Barroso et al., 2000 and Ollero et al., 2001). Furthermore, BDNF is known to up-regulate antioxidants and block the development of oxidative stress (Mattson et al., 2002; Boutahar et al., 2010).

In conclusion, this study demonstrates decreased sperm BDNF mRNA expression together with increased MDA levels from infertile groups. Being an endothelial survival protein, BDNF expression in ejaculated sperm can modulates the cell death machinery and it affects the mitochondrial activity, energy homeostasis and viability of the sperm. Increased oxidative stress from infertile groups may outline the antioxidant role of BDNF. It is notable that decreased testosterone and BDNF mRNA levels highlight their importance in spermatogenesis and sperm maturation. Thus, BDNF could be considered as a potential significant regulator of sperm physiology and hence could play a role in the pathophysiology of male infertility.

\section{REFERENCES}

Aitken. R.J., Buckingham. D. (1992): Enhanced detection of reactive oxygen species produced by human spermatozoa with 7dimethyl amino-naphthalin-1, 2-dicarbonic acid hydrazide. Int. J. Androl., 15:211-219.

Aquila. S., Gentile. M., Middea. E., Catalano. S., Morelli. C., Pezzi. V., Andò. S. (2005): Leptin secretion by human ejaculated spermatozoa. J Clin Endocrinol Metab 2005;90:4753- 61.

Barroso. G., Morshedi. M. and Oehninger. S. (2000): Analysis of DNA fragmentation, plasma membrane translocation of phosphatidylserine and oxidative stress in human spermatozoa. Hum. Reprod., 15: 1338-1344.

Bonni. A., Brunet. A., West. A., Datta. S.R., Takasu. M.A., Greenberg.M. (1999): Cell Survival Promoted by the Ras-MAPK 
Signaling Pathway by Transcription-Dependent and-Independent Mechanisms. Science 286 (5443) pp. 1358-1362

Boutahar. N., Reynaud. E., Lassabliere. F., Borg. J. (2010): Brainderived neurotrophic factor inhibits cell cycle reentry but not endoplasmic reticulum stress in cultured neurons following oxidative or excitotoxic stress. J Neurosci Res; 88:2263-2271.

Donovan. M.J., Lin. M.I., Wiegn. P., Ringstedt. T., Kraemer. R., Hahn. R., Wang. S., Hempstead. B.L. (2000): Brain derived neurotrophic factor is an endothelial cell survival factor required for intramyocardial vessel stabilization. Development 127(21):4531-4540.

Douma. S., Van. Laar. T., Zevenhoven. J., Meuwissen. R., Van. Garderen. E., Peeper. D.S. (2004): Suppression of anoikis and induction of metastasis by the neurotrophic receptor TrkB. Nature 430(7003):1034-1039.

Draper. H.H., Squires. E.J., Mahmoodi. H., Wu. J., Aganval. S. and Hadley. M.A. (1993): A comparative evaluation of thiobarbituric acid methods for the determination of malondialdehyde in biological materials. Free Rad. Biol. Med., 15(4): 353-363.

Goldman S.A., Chen Z.(2013): Testosterone modulation of angiogenesis and neurogenesis in the adult songbird brain. Neuroscience, 3;239:139-48.

Guerin. J.F., Ben Ali. H., Rollet. J., Souchier. C. \& Czuba. J.C. (1986): Alpha-glucosidase as a specific epididymal enzyme marker, its validity for the etiologic diagnosis of azoospermia. J. Androl., 7(3): 156-162.

Grande. I., Fries. G.R., Kunz. M., Kapczinski. F. (2010): The Role of BDNF as a Mediator of Neuroplasticity in Bipolar Disorder. Psychiatry Investig 7(4):243-50

Henkel. R., Muller. C., Miska. W., Schill. W.B., Kleinstein. J., Gips. H. (1995): Acrosin activity of human spermatozoa by means of a simple gelatinolytic technique: a method useful for IVF. J Androl 16: 272-7.

Hinting. A., Schoonjans. F. \& Comhaire. F. (1988): Validation of a single-step procedure for the objective assessment of sperm motility characteristics. Int. J. Androl., 11(4):277-87.

Jurisicova. A., Lopes. S., Meriano. J., Oppedisano. L., Casper. R.F. \& Varmuza. S. (1999): DNA damage in round spermatids of mice with a targeted desruption of the Pplcgamma gene and in 
testicular biopsies of patients with non-obstructive azoospermia. Mol. Hum. Reprod., 5, 323-330.

Kerschensteiner. M., Gallmeier. E., Behrens. L., Leal. V., Misgeld. T., Klinkert. W., Hoppe. E. etal. (1999): Activated Human T Cells, B Cells, and Monocytes Produce Brain-derived Neurotrophic Factor In Vitro and in Inflammatory Brain Lesions: A Neuroprotective Role of Inflammation? J. Exp. Med. Volume 189, Number 5.

Li. C., Zhu. X., Wang. C., Zhuo. Liu., Li. W., Chen. Lu., Xu. Zhou. (2012): The expression and putative role of brain-derived neurotrophic factor and its receptor in bovine sperm Theriogenology 77 636-643

Matthews. V.B., Astrom. M.B., Chan. M.H., Bruce. C.R., Krabbe. K.S., Prelovsek. O. et al., (2009): Brain-derived neurotrophic factor is produced by skeletal muscle cells in response to contraction and enhances fat oxidation via activation of AMP-activated protein kinase. Diabetologia 52: 1409-1418,.

Mattson. M.P., Lovell. M.A., Furukawa. K., Markesbery. W.R. (1995): Neurotrophic factors attenuate glutamate-induced accumulation of peroxides, elevation of intracellular $\mathrm{Ca}^{2+}$ concentration, and neurotoxicity and increase antioxidant enzyme activities in hippocampal neurons. J Neurochem 65: 1740-1751.

Mattson. M.P., Duan. W., Maswood. N. (2002): How does the brain control lifespan? Ageing Res Rev. 1:155-165.

Ming. Y., Bergman. E., Edström. E., Ulfhake. B. (1999): Reciprocal changes in the expression of neurotrophin mRNAs in target tissues and peripheral nerves of aged rats. Neurosci Lett. 273:187-190.

Mirabella. N., Squillacioti. C., Paone. I., Ciarcia. R., Russo. M., Paino. G. (2006): Effects of castration on the expression of brainderived neurotrophic factor (BDNF) in the vas deferens and male accessory genital glands of the rat. Cell Tissue Res. 323:513-522.

Moon. C., Yasuzumi. F., Okura. N., Kim. H., Ahn. M. \& Shin. T. (2005): Enhanced expression of tyrosine kinase receptor a in germ cells of rat testis with acute experimental testicular torsion. Urology International. 74 79-85.

Müller. D., Davidoff. M. S., Bargheer. O., Paust. H. J., Pusch. W., Koeva. Y., Middendoriff. R. (2006): The expression of neurotrophins and their receptors in the prenatal and adult human testis: evidence for functions in Leydig cells. Histochem. Cell Biol.126:199-211. 
Ollero. M., Gil-Guzman. E., Lopez. M.C., Sharma. R.K., Agarwal. A., Larson. K., Evenson. D., Thomas. A.J., Alvarez. J.G. (2001): Characterization of subsets of human spermatozoa at different stages of maturation: Implications in the diagnosis and treatment of male infertility. Hum. Reprod., 16:1912-1921.

Pedersen. B.K. (2011): Muscles and their myokines. The Journal of Experimental Biology. 214, 337-346.

Perrard. M., Vigier. M., Damestoy. A., Chapat. C., Silandre. D., Rudkin. B.B.\& Durand. P. (2007) Nerve growth factor participates in an auto/paracrine pathway of regulation of the meiotic differentiation of rat spermatocytes. Journal of Cellular Physiology. 210 51-62.

Schoonjans. F., Zalata. A. , Depyudt. C.E., Comhaire. F. H. (1995): MedCalc: a new computer program for medical statistics . Computer Methods and Programs in Biomedicine 48 : 257-262.

Seifer. D.B., Feng. B., Shelden. R.M., Chen. S., Dreyfus. C.F. (2002): Brain derived neurotrophic factor: A novel human ovarian follicular protein. J Clin Endocrinol Metab. 87:655-9.

Sinha-Hikim. A.P., Wang. C., Lue. Y., Johnson. L., Wang. X.H. and Swerdloff. R.S. (1998): Spontaneous germ cell apoptosis in humans: evidence for ethnic differences in the susceptibility of germ cells to programmed cell death. J. Clin. Endocrinol. Metab., 83, 152156.

Ukropec. J., Ukropcova. B., Kurdiova. T., Gasperikova. D., Klimes. I. (2008): Adipose tissue and skeletal muscle plasticity modulates metabolic health. Arch Physiol Biochem 114: 357-368

Wang. C.Q., Zhang. J., Sun. Y.F., Wang. D., Li. C.J., Li. W.H., Lu. C., Liu. Z., Wu. H., Hou. X.F. et al. (2013): Detection of neurotrophin-4 (NT-4) in ejaculated bull spermatozoa and its effect on spermatozoa mitochondrial activity. Reproduction in Domestic Animals. Volume 48, Issue 1, p131-136.

WHO (2010): WHO Laboratory Manual for the Examination of Human Semen and Sperm-cervical Mucus Interaction. $4^{\text {th }}$ edn. Cambridge: Cambridge University Press.

Zalata A.A., Ahmed A.H., Allamaneni S.S., Comhaire F.H., Agarwal A. (2004): Relationship between acrosin activity of human spermatozoa and oxidative stress. Asian J. Androl., 6: 313-318. 
Zalata.A, Christophe. A., Depuydt. C.E, Schoonjans. F. and Comhaire. F.H. (1998): The fatty acid composition of phospholipids of spermatozoa from infertile patients. Molecular Human Reproduction vol.4 no.2 pp. 111-118, 1998.

Zalata.A, Hafez .T. and Comhaire. F.H. (1995): Evaluation of the role of reactive oxygen species in male infertility. Hum. Reprod. (1995) 10 (6):1444-1451

Zheng. L., Li. C., Sun. Y., Liu. Z., Zhou. X. (2011): Expression of brain-derived neurotrophic factor in mature spermatozoa from fertile and infertile men. Clin Chim Acta 2011 Jan 14; 412(1-2):44-7.

Zini. A., San Gabriel. M. \& Baazeem. A. (2009): Antioxidant and sperm DNA damage: a clinical prespective. J Assist Reprod Genent 26 (8): 427-32. 


\section{الملخص العربي \\ علاقة التعبير الجيني لعامل التفذية العصبية المشتقة من المخ ، الجها التأكسدي والهرمونات بعقم الرجال \\ عادل عبد القادر زلطة '- أماني عطوة ' --نجلاء مختار ' - محمد خالا' ' ' ' \\ قسم الكيمياء الحيوية الطبية' - قسم الجلدية والتتاسلية كلية الطب ؟ - جامعة المنصورة '}

يلعب عامل التغذية العصبية المشتقة من المخ (BDNF) دورا في تطوير مختلف الأنسجة

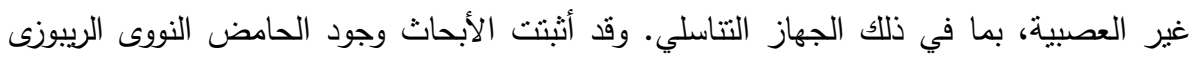

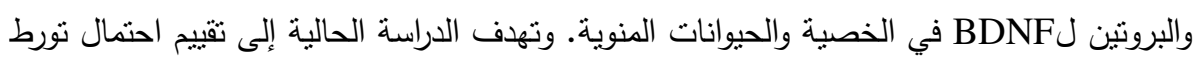
BDNF BDNF

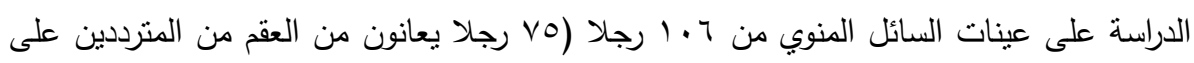

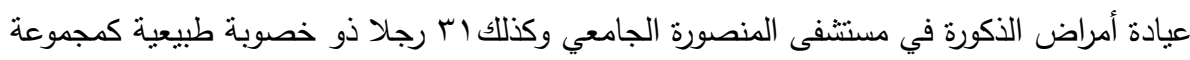
ضابطة) • وقد تم تحليل عينات السائل المنوي طبقا لتوصيات منظمة الصحة العالمية باستخدام

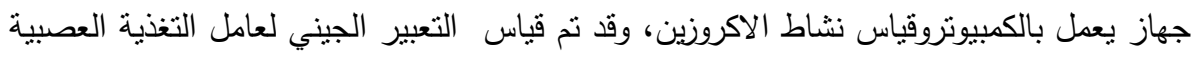
المشتقة من المخ بطريقة النسخ العكسي لتفاعل البلمرة المنسلسل (RT-PCR). وأكدت هذه الدراسة على وجود تعبير جيني لBDNF في الحيوانات المنوية. وقد أظهرت نتائج هذه

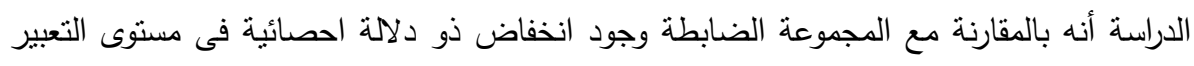

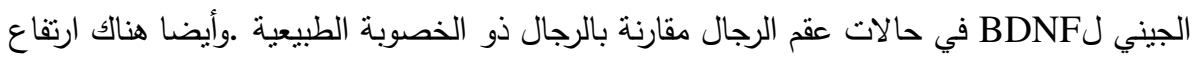
في قياس ثنائي الديهايد المالون (MDA) في حالات العقم وهناك ارتباط ايجابيا فى مسنويات

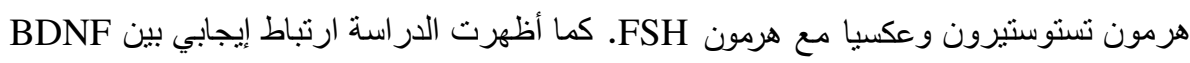

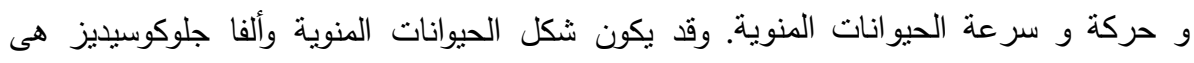
المحددات المحتملة التي تؤثر على التغيير فى التعبير الجينى لBDNF.

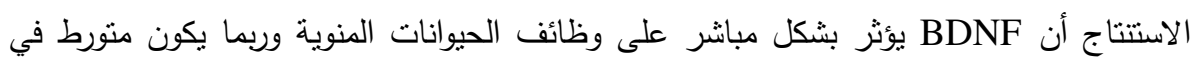

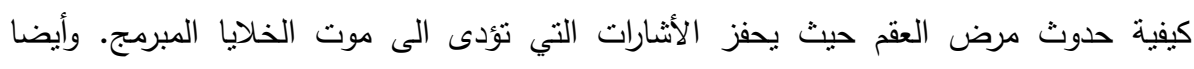

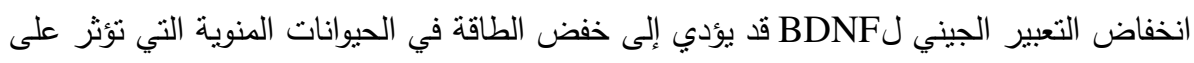

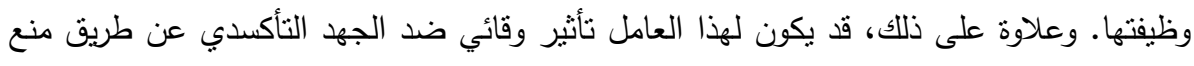
تراكم الأكاسيد الفوقية وزيادة الإنزيمات المضادة للأكسدة. 